\title{
STRUCTURE OF FISH COMMUNITY AND REPRODUCTIVE BIOLOGY OF THREE INDIGENOUS SPECIES OF CYPRINIDS IN KEDUNGOMBO RESERVOIR
}

\author{
Endi Setiadi Kartamihardja*)
}

\begin{abstract}
The study investigated the structure of fish community and the reproductive biology of three indigenous species of cyprinids, namely Puntius gonionotus (Bleeker), Puntius bramoides (Cuvier \& Valenciennes) and Mystacoleucus marginatus (Cuvier \& Valenciennes) in the Kedungombo Reservoir, Central Java. Gillnet sampling in six sub-fishing areas of the reservoir once a month for a 12 month period was carried out. The structure of fish community was analysed descriptively. The study of reproductive biology included estimation of sex ratio, gonado-somatic index (GSI) and fecundity. Results showed that the fish community was composed of twelve species belonging to five families, i.e. six Cyprinidae species, three Cichlidae, one Channidae, one Bagriidae and one Clariidae. Five species, i.e. Oreochromis mossambicus, Puntius gonionotus, Puntius bramoides, Mystacoleucus marginatus and Channa striatus were dominant. These species were distributed all over the reservoir, except for $C$. striatus which was distributed in a specific area covered with grass and bushes. The highest value of species diversity and species richness occurred in the upstream portion of the reservoir. The riverine species which did not adapt well to the lacustrine environment were concentrated in the dendritic riverine portion of the reservoir. Reproduction of $P$. gonionotus, $P$. bramoides and $M$. marginatus started from December until March when the water level of the reservoir began to rise. The sex ratios of the three indigenous species of cyprinids were not signifficantly different from 1:1 ( $\mathrm{P}>0.05)$. Fecundity of $P$. gonionotus, $P$. bramoides and $M$. marginatus were between $25,980-86,916 ; 42,454-99,659$; and 4,702-15,681, respectively. The fecundity was positively correlated with total length, body weight, and gonad weight.
\end{abstract}

KEYWORDS: Fish community, reproductive biology, indigenous species, cyprinids, reservoir.

\section{INTRODUCTION}

Kedungombo Reservoir located in Central Java, Indonesia is a multipurpose reservoir, used for irrigation, hydroelectric power generation, flood control, fisheries and tourism. The dam was built across the Serang River and the area inundated in February 1990. The reservoir has a maximum surface area of 4,950 ha, a drawdown area of $1,750 \mathrm{ha}$, a maximum depth of $57 \mathrm{~m}$ and an average depth of $12.8 \mathrm{~m}$. Based on its limnological characteristics, the reservoir was classified into mesotrophic lake (Krismono and Kartamihardja, 1990).
Capture fisheries and aquaculture were practised in the reservoir. The capture fisheries are dominant and are carried out by the people living in the vicinity of the reservoir. The development of capture fisheries and its management need the knowledge on biology and dynamics of the fish population.

The structure of fish community and their reproductive biology are primary aspects of fisheries biology. Fish species inhabiting a reservoir form a community, the elements of which interact directly or indirectly. The pattern of interactions of individuals defines the organization or structure of a community or sub-community. Species diversity, equitability and dissimi- 
larity provide partial quantitative descriptions of communities or assemblages (Wootton, 1990).

The study on reproductive biology forms a basic part of the biology of fishes. Knowledge of the sex ratio and the state of maturity of individuals in a population is useful, and estimates of fecundity are important in studies of population dynamics and productivity (Scott, 1979; Wootton, 1979).

The objectives of the present study are to investigate biological aspects of the fish community and the reproductive biology of the three indigenous species of cyprinids, Puntius gonionotus, Puntius bramoides, Mystacoleucus marginatus in Kedungombo Reservoir.

\section{MATERIALS AND METHODS}

\section{Sampling Procedure}

Gillnet fish sampling was adopted (FAO, 1975), to provide information on the structure of fish community, distribution, composition, relative abundance and length frequency distribution. Two fleets of monofilament floating gillnets were used. A fleet of gillnets consisted of nine pieces with different mesh sizes. Gillnets dimensions are summarised in Table 1.

Fish sampling was conducted systematically, once a month for 12 months at six sub-fishing areas of the reservoir (Figure 1). The fishing area I and VI are upstream and riverine with relatively high flow and eutrophic habitat. The fishing areas II and V represent a mixing area with a deeper basin, reduced flow and an intermediate trophic level. The fishing areas III and IV are lacustrine, little flow and an oligotrophic environment.

The fleet of gillnets was set prior to sunset and lifted the next morning. The number of fish caught was recorded. The lengths and weights of fish were measured to nearest $1 \mathrm{~mm}$ and $5 \mathrm{~g}$, respectively. The fish samples were dissected and the gut and the gonad were removed, labelled and preserved in $10 \%$ formalin.

Table 1. Description of the gillnets

\begin{tabular}{|c|c|c|c|c|c|c|c|c|c|c|}
\hline \multirow{2}{*}{\multicolumn{2}{|c|}{ Description }} & \multicolumn{9}{|c|}{ Stretched Mesh Size (cm) } \\
\hline & & 2.5 & 3.8 & 5.1 & 6.4 & 7.6 & 8.9 & 10.2 & 11.4 & 12.7 \\
\hline Length of net & $(\mathrm{m})$ & 35 & 35 & 35 & 35 & 35 & 35 & 35 & 35 & 35 \\
\hline Number of mesh der & & 100 & 70 & 50 & 40 & 35 & 30 & 25 & 23 & 20 \\
\hline Area of net & $\left(\mathrm{m}^{2}\right)$ & 62.2 & 65.3 & 62.2 & 62.1 & 65.3 & 65.3 & 62.2 & 64.4 & 62.3 \\
\hline Number of floats & *) & 36 & 36 & 36 & 36 & 36 & 36 & 36 & 36 & 36 \\
\hline Number of sinkers & $* *)$ & 71 & 71 & 71 & 71 & 71 & 71 & 71 & 71 & 71 \\
\hline Diameter of twine & $(\mathrm{mm})$ & 0.2 & 0.2 & 0.2 & 0.2 & 0.2 & 0.2 & 0.2 & 0.2 & 0.2 \\
\hline Hanging ratio & $(\%)$ & 40 & 40 & 40 & 40 & 40 & 40 & 40 & 40 & 40 \\
\hline
\end{tabular}

*) Polypropylene float

**) Lead sinker with a weight of $25 \mathrm{~g}$

\section{Structure of Fish Community}

The analysis of the structure of the fish communities were based on the data of the experimental gillnet catches. The species diversity and richness were analysed descriptively.

\section{Reproductive Biology}

The sexual characteristics of the fish species were identified internally by observing their gonads. The ratio of female to male was tested statistically using Chi-square test. Sexual 


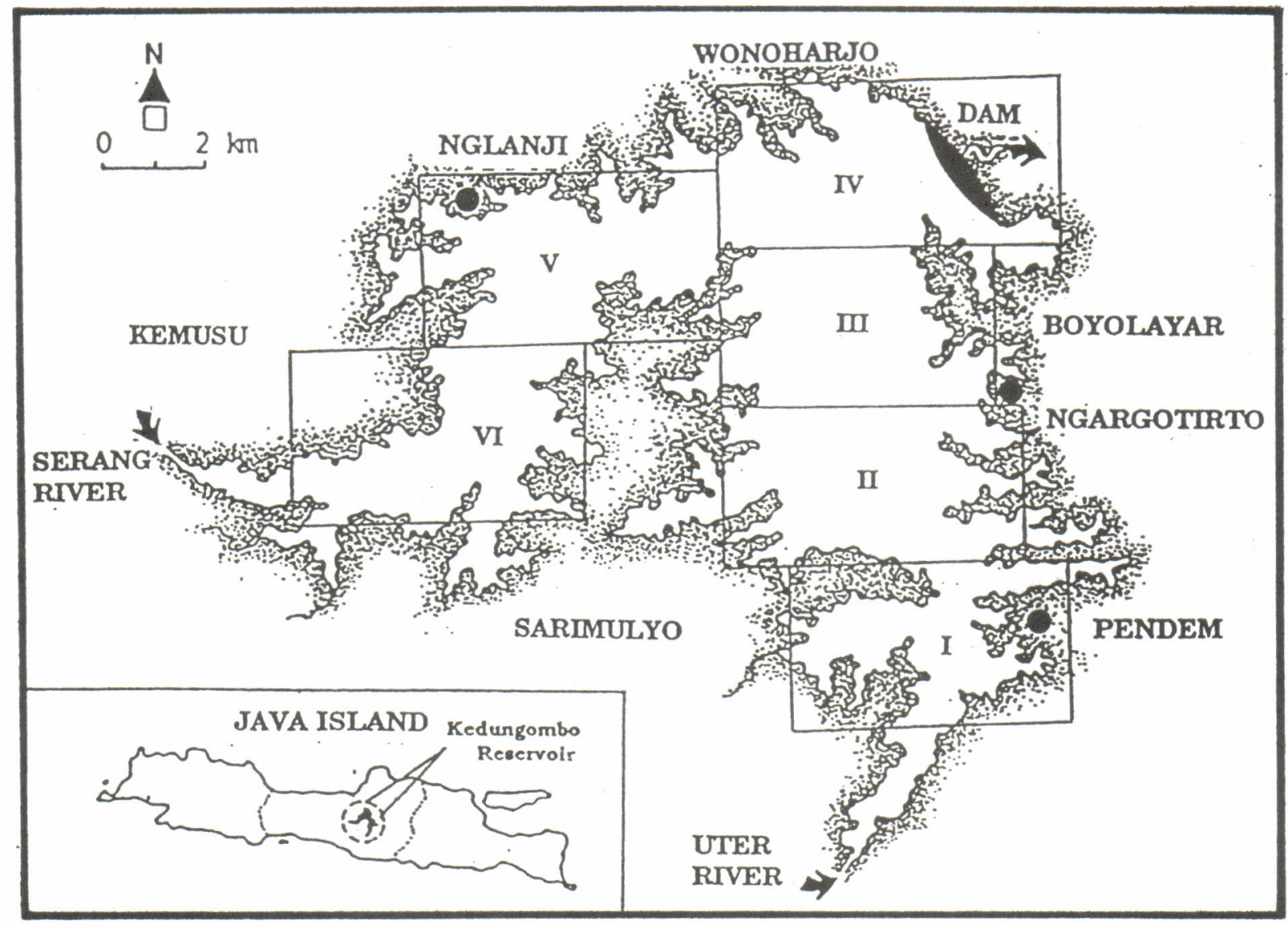

Figure 1. Map of the Kedungombo reservoir showing six sub-fishing areas.

maturity of fish was based on the following method described by De Silva (1973):

stage I: immature, impossible to distinguish female from male macroscopically,

II: unmistakably an ovary, very small, egg cells small,

III: ovary fuller, eggs not yellow,

IV: ovary full, almost filling body cavity, eggs yellow,

V: ovary full, completely filling body cavity, eggs extruded under slight pressure on the belly,

VI: a few yellow eggs, but ovary not full, wrinkled and reddish.

Gonado-somatic Index (GSI) is defined as the ratio of gonad weight to body weight expressed as a percentage. The GSI and its variation over the 12 month sampling period were studied from females of maturity stage $\mathrm{V}$.

Fecundity (absolute fecundity) defined as the number of ripening eggs found in the ovaries of mature females (Bagenal, 1978) was also examined. The fecundities of the three species were examined using a gravimetric method (Bagenal and Braum, 1978). The regression equation between fecundity and length of fish, fecundity and weight of fish, and fecundity and weight of ovary were constructed.

\section{RESULTS}

\section{Structure of Fish Community}

The fish from experimental gillnets consisted of twelve species (Table 2). 
Table 2. List of fish species caught with experimental gillnets in the Kedungombo Reservoir.

\begin{tabular}{|c|c|c|c|}
\hline No. & Local Name & Scientific Name & Family \\
\hline 1. & Mujair & Oreochromis mossambicus Peters & Cichlidae \\
\hline 2. & Nila & Oreochromis niloticus (L.) & Cichlidae \\
\hline 3. & Nila Merah*) & O. mossambicus (\$) x O. niloticus $\left(\mathrm{\sigma}^{7}\right)$ & Cichlidae \\
\hline 4. & Tawes & Puntius gonionotus (Blkr.) & Cyprinidae \\
\hline 5. & Lelawak & Puntius bramoides (C.V.) & Cyprinidae \\
\hline 6. & Wader & Mystacoleucus marginatus (C.V.) & Cyprinidae \\
\hline 7. & Waderpari & Rasbora argyrotaenia (Blkr.) & Cyprinidae \\
\hline 8. & Gilik & Tylognathus hispidus (C.V.) & Cyprinidae \\
\hline 9. & Karper & Cyprinus carpio L. & Cyprinidae \\
\hline 10. & Garingan & Mystus nigriceps (C.V.) & Bagridae \\
\hline 11. & Kutuk & Channa striatus (Bl.) & Channidae \\
\hline 12. & Lele & Clarias batrachus (L.) & Clariidae \\
\hline
\end{tabular}

*) nila merah (red tilapia) is a hybrid of a mutant orange $O$. mossambicus and a normal color grey $O$. niloticus (Hardjamulia and Wardoyo, 1991)

Oreochromis mossambicus, Puntius gonionotus, Puntius bramoides and Mystacoleucus marginatus were the dominant species from the gillnets. Commercial gillnet catches produced similar results, but the longline fishing had Channa striatus as its dominant species.

The numbers of fish caught with gillnets according to sub-fishing areas of the reservoir are presented in Table 3. Based on the number of specimens caught, the distributions of Channa striatus, Mystus nigriceps, Clarias batrachus, Tylognathus hispidus, Cyprinus carpio and red tilapia were limited to specific areas. C. striatus was mainly found in areas with grass and bushes of sub-fishing areas III and V. Mystus nigriceps. $T$. hyspidus and $C$. batrachus were found in the upstream of the reservoir (the sub-fishing area I and VI). Cyrpinus carpio and red tilapia were found in the sub-fishing areas III, IV and V where the floating net cages culture exist.

The sub-fishing areas I, II, V and VI all had large number of $O$. mossambicus while the abundance of this species in sub-fishing areas III and IV was much lower. The sub-fishing areas I, II, V and VI were the upstream portions of the reservoir where the Serang and the Uter Rivers, still influence the environment.

\section{Reproductive Biology}

In this study, the sex ratio of the three species were not significantly different from $1: 1(\mathrm{P}>0.05)$ (Table 4).

Figure 2 shows the gonado-somatic index according to the maturity stages. For all species, the GSI increased with the increasing maturity until stage $\mathrm{V}$ then it declined in the stage VI.

The GSI of spawning females, $P$. gonionotus varied from $2.95-15.83 \%$, in $P$. bramoides 8.43 $23.38 \%$, and in $M$. marginatus $1.60-3.00 \%$ (Table $5)$. The GSIs of females of the three species showed single peaks, being January for $M$. marginatus and March for the other two species (Figure 3). The GSI of females $M$. marginatus remained low, troughout the year.

Among the three species of cyrpinids, $P$. bramoides had the highest absolute fecundity though $M$. marginatus had the highest relative fecundity (number of eggs/g of flesh). First maturity occurred at length of $16.5 \mathrm{~cm}$ in $P$. gonionotus, $15.5 \mathrm{~cm}$ in $P$. bramoides and $12.5 \mathrm{~cm}$ in $M$. marginatus. The relationship between fecundity and total length, body weight, and gonad weight are shown in Table 6 . 
Kartamihardja, E.S.

Table 3. Number of fish species caught with gillnets in six sub-fishing areas over twelve months period.

\begin{tabular}{|c|c|c|c|c|c|c|c|}
\hline \multirow{2}{*}{ Fish Species } & \multicolumn{6}{|c|}{ Sub Fishing Area } & \multirow{2}{*}{ Total } \\
\hline & I & II & III & IV & V & VI & \\
\hline O. mossambicus & 1092 & 557 & 92 & 122 & 548 & 552 & 2963 \\
\hline O. niloticus & 3 & 18 & 2 & 2 & 5 & 2 & 32 \\
\hline Red tilapia & - & - & - & - & 3 & - & 3 \\
\hline P. gonionotus & 288 & 360 & 180 & 468 & 324 & 73 & 1693 \\
\hline P. bramoides & 355 & 211 & 250 & 296 & 362 & 224 & 1698 \\
\hline M. marginatus & 72 & 109 & 426 & 281 & 118 & 54 & 1060 \\
\hline C. carpio & - & 1 & - & - & 1 & - & 2 \\
\hline R. argyrotaenia & 25 & 66 & 2 & - & 2 & 5 & 100 \\
\hline T. hispidus & 7 & & - & & 1 & 2 & 10 \\
\hline C. striatus & - & - & 4 & & 5 & - & 9 \\
\hline M. nigriceps & 2 & - & - & - & - & 2 & 4 \\
\hline C. batrachus & 1 & - & & - & & 1 & 2 \\
\hline Total & 1845 & 1322 & 956 & 1169 & 1369 & 915 & 7576 \\
\hline
\end{tabular}

Table 4. Sex ratio of mature specimen of the three indigenous fish species of Cyprinids in Kedungombo Reservoir.

\begin{tabular}{lccccc}
\hline Fish Species & Female & Male & Sex Ratio & $\mathbf{X}_{\text {cal. }}$ & $\mathbf{X}_{\text {(0.05) }}$ \\
\hline P. gonionotus & 29 & 26 & $1: 1.12$ & 0.16 & 3.481 \\
P. bramoides & 27 & 23 & $1: 1.07$ & 0.04 & \\
M. marginatus & 36 & 31 & $1: 1.13$ & 0.37 & \\
\hline
\end{tabular}

$\mathrm{X}_{\mathrm{cal}}=$ chi-square calculated

\section{DISCUSSION}

Fish in Kedungombo Reservoir were originally native species native to Serang river and its tributaries. Krismono and Kartamihardja (1990) found eight native species inhabiting the Serang River and its tributaries. However, after the reservoir was impounded the fish composition changed. In the present study, twelve species of fishes were caught. Four of these, i.e. C. carpio, $O$. mossambicus, $O$. niloticus and red tilapia were introduced species. Recently, five species, i.e. $\boldsymbol{O}$. mossambicus, $P$. gonionotus, $P$. bramoides, $M$. marginatus and $C$. striatus are dominant although the latter is not important in the gillnet fishery. Although a riverine fish fauna may be generally adapted poorly to the lacustrine envi- 
Table 5. Gonado-somatic Index and fecundity of the three indigenous fish species of Cyprinids in Kedungombo Reservoir.

\begin{tabular}{lcccccc}
\hline \multicolumn{1}{|c}{ Fish Species } & $\mathbf{N}$ & $\begin{array}{c}\text { Total } \\
\text { Length } \\
\mathbf{( c m )}\end{array}$ & $\begin{array}{c}\text { Body } \\
\text { Weight } \\
\mathbf{( g )}\end{array}$ & $\begin{array}{c}\text { Gonad } \\
\text { Weight } \\
\mathbf{( g )}\end{array}$ & $\begin{array}{c}\text { GSI } \\
\mathbf{( \% )}\end{array}$ & $\begin{array}{c}\text { Fecundity } \\
\text { (Number of eggs) }\end{array}$ \\
\hline P. gonionotus & 29 & $16.5-36.0$ & $60-800$ & $9.50-27.70$ & $2.95-15.83$ & $25980-86916$ \\
P. bramoides & 27 & $15.5-26.6$ & $50-230$ & $11.69-28.31$ & $8.43-23.38$ & $42454-99659$ \\
M. marginatus & 36 & $12.5-14.0$ & $20-35$ & $0.40-1.05$ & $1.60-3.00$ & $4702-15681$ \\
\hline
\end{tabular}

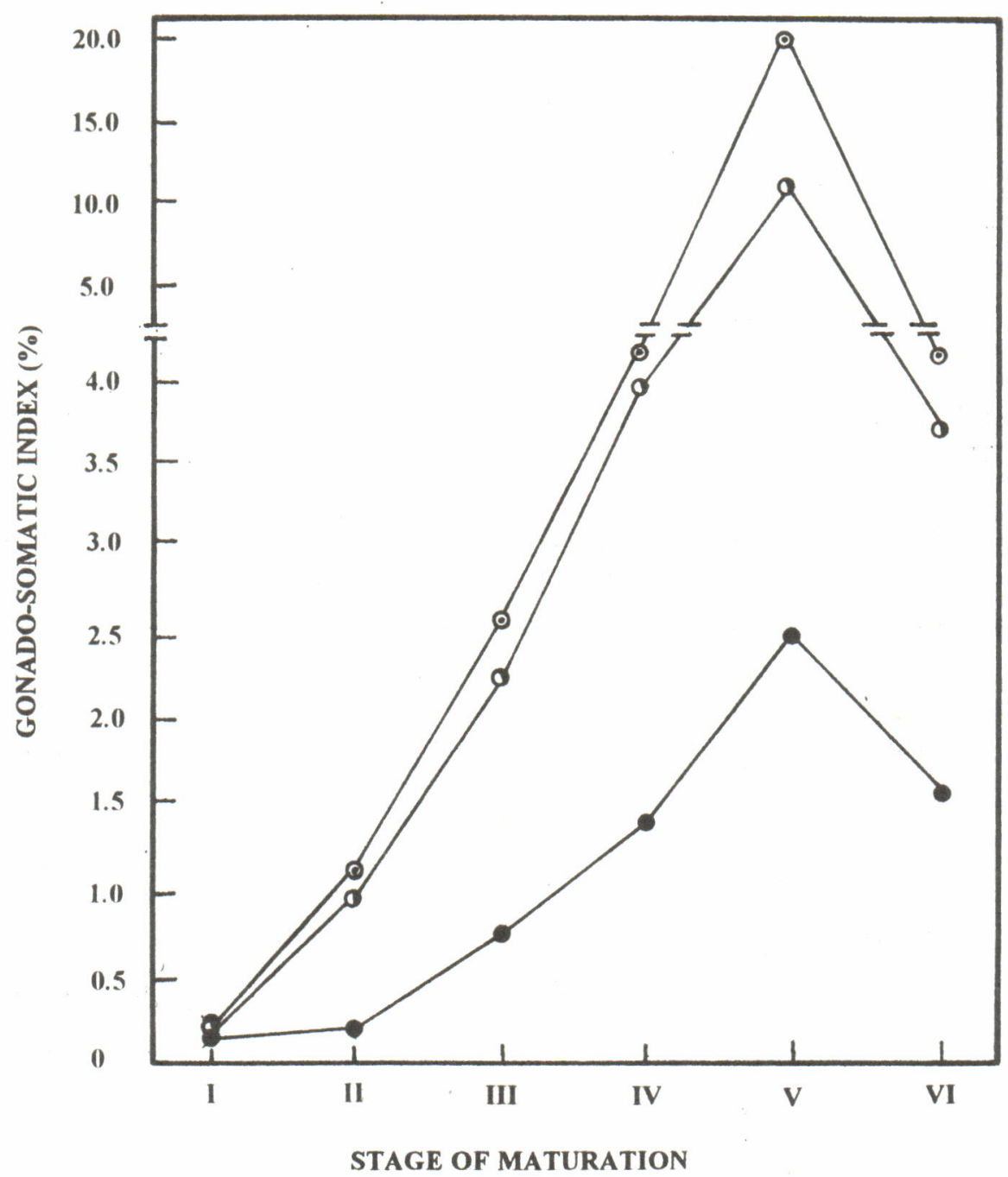

Figure 2. Changes in gonado somatic index ini relation to stages of maturation in female Puntius gonionotus, Puntius bramoides and Mystacoleucus marginatus. 
Kartamihardja, E.S.

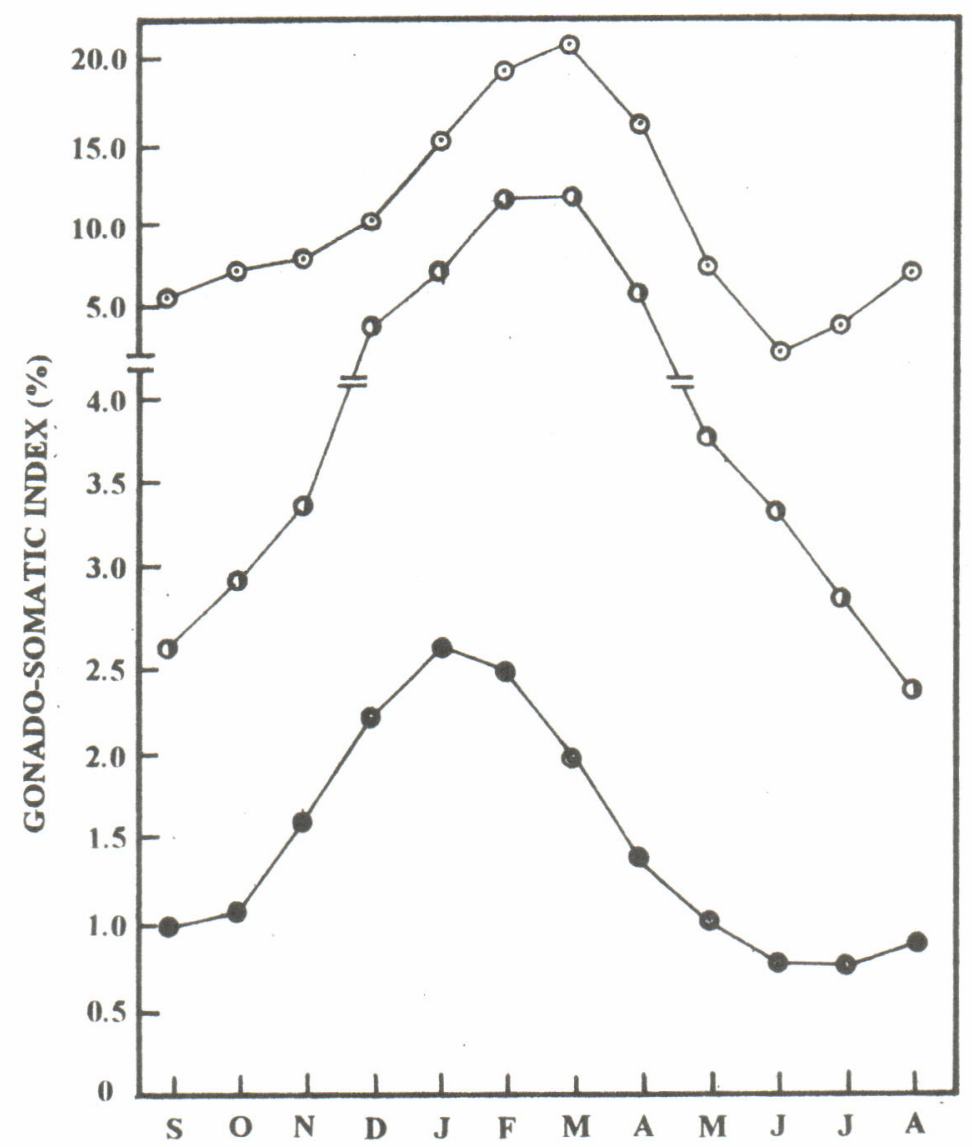

Figure 3. Monthly variation in gonado somatic index of female Puntius gonionotus, Puntius bramoides and Mystacoleucus marginatus.

Table 6. The relationship between fecundity (f) and total length, body weight, and gonad weight of the three indigenous species of Cyprinids in Kedungombo Reservoir.

\begin{tabular}{lllll}
\hline Fish Species & Parameter & Relationship & r & N \\
\hline P. gonionotus & Total Length (L) & $\operatorname{logF}=2.7809+1.4084 \log \mathrm{L}$ & 0.922 & 29 \\
& Body Weight (W) & $\mathrm{F}=34422.2+79.9 \mathrm{~W}$ & 0.791 & 29 \\
& Gonad Weight (Gw) & $\mathrm{F}=102.83+3026.11 \mathrm{Gw}$ & 0.995 & 29 \\
P. bramoides & Total Length (L) & $\operatorname{logF}=3.4462+0.9836 \log \mathrm{L}$ & 0.772 & 27 \\
& Body Weight (W) & $\mathrm{F}=26131.6+258.1 \mathrm{~W}$ & 0.882 & 27 \\
& Gonad Weight (Gw) & $\mathrm{F}=2779.51+3544.03 \mathrm{Gw}$ & 0.994 & 27 \\
& Total Length (L) & $\operatorname{logF}=-0.380+3.848 \operatorname{logL}$ & 0.635 & 36 \\
& Body Weight (W) & $\mathrm{F}=-8482.5+597.9 \mathrm{~W}$ & 0.727 & 36 \\
& Gonad Weight (Gw) & $\mathrm{F}=-186.08+12757.87 \mathrm{Gw}$ & 0.978 & 36 \\
\hline
\end{tabular}


ronment (Fernando and Holcik, 1982), several species in the Kedungombo Reservoir have adapted well. Four of the dominant species, namely $O$. mossambicus, $P$. gonionotus, $P$. bramoides and $M$. marginatus were distributed all over the reservoir. Those of the four species prefer to live in a lacustrine environment. Channa striatus was found in specific areas covered with grass and bushes where Rasbora argyrotaenia and shrimp were abundant. Similar conditions were found in Kelang River, Malaysia where C. striatus was present in habitats with high densities of small cyprinid fishes (Mohsin and Law, 1980). Wootton (1990) stated that the distribution of fish species is correlated with feeding habits and reproductive activities. The riverine species which could not adapt well to lacustrine environment such as Mystus nigriceps, Tylognathus hispidus and Clarias batrachus were concentrated in the dendritic part of riverine portion of the reservoir. Those of three species are known as a bottom living and they feed on bottom organism.

Sub-fishing areas I, II, and V have the higher species diversity than the other areas (Table 3). It was understood that sub-fishing areas I, II, and $\mathrm{V}$ were the areas rich in nutrients derived from the rivers and were mainly shallow. Eventhough sub-fishing area VI is also rich in nutrients and shallow, the area is more turbid compare to the areas I, II, and V. Therefore, the species diversity in the area VI is lower than the areas I, II and V.

Study on reproductive biology indicated that the sex ratios of the three species of cyprinids were not significantly different from 1 . It indicated that the mating system of the species can be categorize into a monogamy, mating partners remain together. The same sex ratios has also been noted in the cyprinid species, Barbus nigrofasciatus, B. titteya, B. cumingi, B. bimaculatus and $B$. dorsalis (De Silva et al., 1985). The highest fecundity occurred in $P$. bramoides ranged from 42,454-99,659 eggs. The fecundity of $M$. marginatus was found similar to the described in earlier studies (Satria, 1991). The relationship between fecundity and total length, fecundity and weight, and fecundity and gonad weight showed that the fecundity increased with the increasing total length, weight and gonad weight. For all species, the best relationship was between the fecundity and gonad weight. It indicated that egg weight of the species were not highly varried.
Highest GSI was found in P. bramoides female, denoting greater gonad weight. Changes in the GSI in relation to stage of maturity showed that pattern of variation in the GSI was similar for all species. The GSI seemed to increase from maturation stage I reaching up to the peak at maturation stage V. The GSI then decreased indicating a decrease in the gonad weight due to the release of the ova in the spawning season. The same pattern was also found in Puntius sarana (Chandrasoma and De Silva, 1981). Wootton (1979) sugested that such tropical species which have an extended breeding season with females spawning many times, show smaller changes in the amplitude of the GSI than those with a short season. Of the species presently investigated show greater changes in the amplitude of the GSI, suggesting that they would shed their eggs at once, individuals having a very short spawning period. Monthly variation of the GSI of $P$. gonionotus, $P$. bramoides, $M$. marginatus showed a single peak of the GSI occurring between December and March. This mean that spawning activity of $P$. gonionotus, $P$. bramoides and $M$. marginatus start in December when the water level began to rise and proceed until March. Similar spawning activity of cyprinids was found occurring in Jatiluhur Reservoir (Hardjamulia et al., 1988).

\section{CONCLUSION}

Management of habitat and fish population might be based on biological aspects investigated in this study. Spawning activity of the three indigenous species of cyprinids, $P$. gonionotus, $P$. bramoides and $M$. marginatus occurred in specific areas of the reservoir between December and March. According to these findings, regulation of fishing activities in specific areas could be beneficialand could include a closed season to protect spawning activities between December and March.

\section{REFERENCES}

Bagenal, T.B. 1978. "Aspects of Fish Fecundity." In S. Gerking (ed.) Ecology of Freshwater Fish Production. Blackwell Sci. Publ., Oxford, pp. 75-102.

Bagenal, T.B. and E. Braum. 1978. "Eggs and Early Life History." In T.B. Bagenal (ed.) Methods for Assessment of Fish Production in Freshwaters. 3rd 
ed. IBP Hand book No.3, Blackwell Scientific Publication, Oxford, pp. 165-202.

Chandrasoma J. and S.S. De Silva.1981. "Reproductive biology of Puntius sarana, an indigenous species, and Tilapia rendalli (melanopleura), an exotic in an Ancient Man-made Lake in Sri Lanka". Fish. Mgmt., 12(1): 17-28.

De Silva, S.S., J. Schut and K. Kortmulder. 1985. "Reproductive biology of six Barbus species indigenous to Sri Lanka". Environmental Biology of Fishes, 12 (3): 201-218.

De Silva, S.S. 1973. "Aspects of the Reproductive Biology of the Sprat, Spratus spratus (L.) in Inshore Waters of the West Coast of Scotland". J. Fish. Biol., 5: 689-705.

FAO. 1975. Lake Nasser Development Centre, Aswan Arab Republic of Egypt. A Fish Stock Monitoring Programme for Lake Nasser, based on the Work of H.F. Henderson. Tech Rep. 6, Rome, 31p.

Fernando, C.H. and J. Holcik. 1982. "The Nature of Fish Communities: A Factor Influencing the Fishery Potential and Yield of Tropical Lakes and Reservoirs". Hydrobiologia, 97: 127-140.

Hardjamulia, A., E. Setiadi K., and I.N.S. Rabegnatar. 1988. "Some Biological Aspects of Predominant Fish Species in the Jatiluhur Reservoir, West Java, Indonesia." In De Silva, S.S. (ed.) Reservoir Fishery Development and Management in Asia. Proc. of A Workshop Held in Kathmandu, Nepal, 23-28 November 1987. IDRC. Ottawa, Ont., 98-104p.
Hardjamulia, A. and S.E. Wardoyo. 1991. "The Role of Tilapia in Capture Fisheries and Aquaculture in Open Waters in Indonesia". Paper Presented in the Workshop on Tilapia in the Capture and Culturebased Fisheries in the Indo-Pacific Region. Fifth IPFC Working Party of Experts on Inland Fisheries, Bogor 27-29 June 1991.

Krismono and E.S. Kartamihardja. 1990. Penelitian Biolimnologi di Waduk Kedungombo pada Tahap Prainundasi. Laporan Penelitian Sub Balai Penelitian Perikanan Air Tawar, Jatiluhur, 15p.

Mohsin, A.K.M. and A.T. Law. 1980. "Environmental Studies of Kelang River II, Effects on Fish". The Malayan Nat. J., 33 (3-4): 189-199.

Satria, H. 1991. "Aspek Reproduksi Biologi Ikan Beunteur (Puntius binotatus) dan Genggehek (Mystacoleucus marginatus) di Waduk Cirata, Jawa Barat". Bull. Penelitian Perikanan Darat, 10(2): 4048.

Scott, D.B.C. 1979. "Environmental Timing and the Control of Reproduction in Teleost Fishes". Sym. Zool. Soc. Lond., 44: 105-132.

Wootton, R.J. 1979. "Energy Cost of Eggs Production and Environmental Determinants of Fecundity in Teleost Fishes". Sym. Zool. Soc. Lond., 44: 133-159.

Wootton, R.J. 1990. Ecology of Teleost Fishes. Fish and Fisheries Series 1. Chapman and Hall Ltd., London, 404p. 